\title{
KUALITAS LAYANAN PADA GALERI INVESTASI UNIVERSITAS \\ BUNDA MULIA DENGAN MENGGUNAKAN METODE SERVQUAL
}

\author{
Novita $^{1)}$, Lelly Christin ${ }^{2)}$ \\ Fakultas Ilmu Sosial dan Humaniora, Universitas Bunda Mulia \\ email $^{1)}$ :novita@bundamulia.ac.id \\ email2): 1christin@bundamulia.ac.id
}

\begin{abstract}
The existence of Galeri Investasi at the campus is a part of the function of BEI to educate the public, especially students, about capital market investment. Galeri Investasi UBM aims to educate prospective generation of people to be able to play at the capital market in Indonesia. Galeri Investasi UBM has won Billionaire Campus Award. Achievements that have been achieved by the Galeri Investasi UBM also continue to be followed by an increase in service quality. Population of this research is the investor at Galeri Investasi UBM as listed as an active student. This study used a servqual models technique. The results showed that the strategic location of Galeri Investasi UBM should be maintained, while internet access / wifi in the Galeri Investasi UBM is the criterion that need to be improved because it has the lowest score.
\end{abstract}

Keywords: servqual model, investment galery, stock market.

\begin{abstract}
Abstrak
Keberadaan galeri investasi di kampus adalah bagian dari fungsi BEI untuk memberikan edukasi kepada masyarakat, terutama mahasiswa, mengenai investasi pasar modal. Galeri Investasi UBM bertujuan untuk mendidik para calon generasi bangsa untuk bisa bermain dalam pasar modal di Indonesia. Galeri Investasi UBM telah meraih Campus Billionaire Award. Pencapaian yang telah diraih oleh Galeri Investasi juga terus diikuti dengan peningkatan kualitas pelayanannya. Populasi dalam penelitian ini adalah investor pada Galeri Investasi UBM yang masih aktif tercatat sebagai mahasiswa UBM. Penelitian ini menggunakan teknik servqual model. Hasil penelitian menunjukkan bahwa lokasi Galeri Investasi UBM yang strategis perlu dipertahankan, sedangkan akses internet/wifi di Galeri Investasi UBM merupakan kriteria yang paling perlu untuk diperbaiki karena memiliki nilai skor terendah.

Kata kunci: servqual model, Galeri Investasi, pasar modal
\end{abstract}

\section{PENDAHULUAN}

Bagi setiap orang, investasi merupakan suatu hal yang sangat penting untuk menambah penghasilan dan memberi jaminan akan masa depan. Salah satu cara berinvestasi adalah melalui investasi di pasar modal. Di Indonesia, investasi di pasar modal merupakan hal yang masih jarang untuk dilakukan, padahal menjanjikan keuntungan yang sangat tinggi. 
Contohnya, ketika pertama kali dibuka pada tahun 1992, indeks harga saham gabungan (IHSG) hanya sebesar 300. Namun saat ini, IHSG telah meroket jauh, bahkan hingga menyentuh angka 500. Hanya investasi di pasar modal yang dapat memberikan keuntungan naik sampai 10 kali lipat (sindonews.com, 21 November 2013).

Sampai dengan tahun 2013, jumlah orang yang berinvestasi di pasar modal masih jauh dari ideal. Dengan populasi masyarakat Indonesia yang lebih dari 240 juta jiwa, idealnya ada satu persen masyarakat yang berinvestasi di pasar modal, yaitu kurang lebih 2,2 juta hingga 2,4 juta jiwa. Namun kenyataannya, secara nasional jumlah investor pasar modal masih berkisar 400.000 orang. Untuk mencapai angka ideal tersebut, Bursa Efek Indonesia (BEI) memiliki sasaran bahwa pada tahun 2015, angka ideal 2,2 juta masyarakat yang berinvestasi di pasar modal dapat tercapai.

Hal ini disampaikan oleh Direktur BEI, Hamdi Hassyarbaini saat melakukan kunjungan ke
Malang pada pertengahan Mei 2013 (Surya Online, 27 Mei 2013). Oleh karena itu, tak heran apabila sejak pertengahan tahun 2013, BEI getol mendorong masyarakat untuk berinvestasi di pasar modal. Guna meningkatkan jumlah investor, salah satu strategi yang dilakukan oleh BEI adalah mendirikan Galeri Investasi yang berlokasi di perguruan tinggi.

Hal ini dianggap perlu dilakukan karena banyak anak muda Indonesia, khususnya mahasiswa, dinilai belum paham terkait investasi di pasar modal. Berdasarkan data Badan Pusat Statistik (2013) menyebutkan bahwa jumlah penduduk Indonesia pada tahun 2014 telah mencapai 252,16 juta jiwa. Sebagian besar atau sekitar 48,8 persen penduduk Indonesia berada dalam kelompok umur muda (varia.id, 11 April 2015).

Keberadaan galeri investasi di kampus adalah bagian dari fungsi BEI untuk memberikan edukasi kepada masyarakat, terutama mahasiswa, mengenai investasi pasar modal. Investasi di pasar modal sangat menguntungkan bagi masyarakat. Galeri Investasi BEI 
merupakan sarana pembibitan investor baru, tenaga professional di bidang pasar modal, dan calon professional di emiten dari kalangan akademisi perguruan tinggi (bisnis.com, 8 Oktober 2015). Sampai dengan Oktober 2015, tercatat 140 Galeri Investasi telah tersebar di berbagai universitas di Indonesia, dan diperkirakan mencapai 150 Galeri Investasi di akhir tahun 2015 (okezone.com, 2 Oktober 2015).

Pada hari Rabu, 2 Oktober 2013, telah diresmikan Galeri Investasi Bursa Efek Indonesia di Universitas Bunda Mulia. Galeri yang merupakan hasil kerjasama antara Universitas Bunda Mulia dengan Bursa Efek Indonesia dan MNC Securities tersebut bertujuan untuk memasyarakatkan pasar modal dan kegiatan ilmiah bagi mahasiswa di Universitas Bunda Mulia.

Galeri Investasi yang berada di lantai 2 Universitas Bunda Mulia ini bertujuan untuk mendidik para calon generasi bangsa untuk bisa bermain dalam pasar modal di Indonesia. Untuk pembukaan account-nya hanya memerlukan uang sebesar
Rp.1 juta, maka mahasiswa sudah bisa memulai investasi di pasar modal dan bisa bertransaksi secara online. Selain itu, para mahasiswa juga mendapatkan laporan saham setiap paginya, mengetahui data laporan keuangan perusahaan yang sudah go public serta dapat berkonsultasi langsung di galeri ini . Keberadaan Galeri Investasi ini diharapkan dapat memberi dampak positif bagi mahasiswa. Tujuannya agar semua mahasiswa UBM menjadi antusias dan aktif dalam berinvestasi di bursa pasar modal (liputan6.com, 28 Oktober 2013).

Pada tanggal 8 April 2015, PT. Indosat bekerjasama dengan PT. BEI dan PT. Winratama Perkasa (WinGamers) mengadakan program Indosat Stock Trading Contest (ISTC) di Gedung Bursa Efek Indonesia. ISTC merupakan program kompetisi yang bertujuan sebagai media sosialisasi dan pembelajaran dalam melakukan investasi atau transaksi saham secara virtual yang mengacu kepada sejumlah saham pilihan yang diperdagangkan di BEI secara "realtime" (varia.id, 11 April 2015). Pada kompetisi ini, Galeri 
Investasi UBM meraih Campus

Billionaire Award.

Pencapaian yang telah diraih

oleh Galeri Investasi juga terus diikuti dengan peningkatan kualitas layanannya. Layanan yang baik dapat memotivasi dan mengembangkan minat mahasiswa untuk berinvestasi di pasar modal. Layanan yang baik juga dapat membantu mahasiswa untuk secara antusias aktif melakukan transaksi di pasar modal. Bahkan layanan yang baik dapat mencipta bibit-bibit investor baru, tenaga professional di bidang pasar modal dan calon professional di emiten dari kalangan akademisi Universitas Bunda Mulia (Brady, 2011; Radder and Han, 2008; Sureshchandar et al., 2013). Rumusan masalah dalam penelitian ini ditentukan sebagai berikut :

"Bagaimanakah kualitas layanan pada Galeri Investasi Universitas Bunda Mulia dengan menggunakan metode SERVQUAL?"

Tujuan penelitian ini adalah mengetahui bagaimana kualitas layanan pada Galeri Investasi Universitas Bunda Mulia dengan menggunakan metode SERVQUAL.
Galeri Investasi UBM selalu berusaha memberikan layanan terbaik kepada para investornya. Tetapi persepsi telah memberikan layanan yang terbaik dari pengurus Galeri Investasi UBM belum tentu dipersepsikan secara baik juga oleh investor. Disini perlu adanya kesesuaian antara kualitas layanan yang diharapkan dan kualitas layanan yang didapatkan. Investor akan merasa puas apabila layanan yang disediakan oleh pihak Galeri Investasi UBM sesuai dengan harapannya, sehingga tidak terjadi kesenjangan (gap) antara harapan dan pelayanan yang diperoleh (Yavas et al, 2013; Awan and Mahmood, 2011; Caruana, 2012; Li et al., 2011; Qin and Prybutok, 2008).

Dalam penelitian ini metode servqual digunakan untuk menentukan atribut serta mengukur kesenjangan antara harapan dengan persepsi terhadap layanan Galeri Investasi UBM. Penelitian ini diharapkan mampu memberikan masukan atau rekomendasi kepada pihak Galeri Investasi UBM, terutama untuk investor yang tercatat 
sebagai mahasiswa aktif UBM. Sebagian dari mereka melakukan transaksi di Galeri Investasi hanya karena tuntutan perkuliahan. Setelah perkuliahan selesai, mereka memilih untuk tidak aktif lagi bertransaksi. Dengan adanya layanan yang sesuai atau melebihi harapan, dapat mendorong mahasiswa untuk lebih antusias dan aktif dalam melakukan transaksi di pasar modal berdasarkan niatnya sendiri. Niscaya hal ini dapat menciptakan bibit-bibit investor baru, tenaga professional di bidang pasar modal dan calon professional di emiten dari kalangan akademisi Universitas Bunda Mulia, sesuai dengan harapan terbentuknya Galeri Investasi Universitas Bunda Mulia.

\section{RERANGKA KONSETUAL DAN PERUMUSAN HIPOTESIS}

\section{Kualitas Layanan}

\section{Pemasaran} diharapkan berfokus terhadap kualitas layanan, karena rendahnya kualitas layanan akan menempatkan perusahaan pada kerugian kompetitif. Kerugian kompetitif tersebut dapat berpotensi mengusir pelanggan yang tidak puas. Personel perusahaan membutuhkan pemahaman yang cukup untuk mengatasi isu-isu seperti pengukuran kualitas layanan, identifikasi penyebab kekurangan kualitas layanan, serta merancang dan mengimplementasikan tindakan pemulihan layanan.

Terdapat berbagai perspektif mengenai kualitas layanan sebagai berikut (Lovelock et al., 2011) :

1. Pandangan transeden mengenai kualitas dengan keunggulan bawaannya. Sudut pandang ini sering diterapkan pada seni pertunjukan dan visual. Pandangan ini berpendapat bahwa orang belajar untuk mengenali kualitas hanya melalui pengalaman yang diperoleh dari paparan berulang. Namun dari sudut pandang praktis, manajer atau pelanggan menilai kualitas dari sesuatu yang menurut mereka tidak terlalu membantu.

2. Pendekatan berbasis manufaktur didasarkan pada persediaan dan terutama sangat memerhatikan praktik-praktik teknik manufaktur. Pendekatan ini berfokus pada kesesuaian spesifikasi yang dikembangkan secara internal, yang sering kali 
dipicu oleh tujuan produktivitas dan pengamanan biaya.

3. Definisi berbasis pengguna dimulai dengan pendapat bahwa kualitas terletak di mata orang yang melihatnya. Definisi ini menyamakan kualitas dengan kepuasan maksimum. Pandangan yang subyektif dan berorientasi pada kebutuhan ini mengakui bahwa pelanggan yang berbeda memiliki keinginan dan kebutuhan yang berbeda pula.

4. Definisi berbasis nilai mendefinisikan kualitas dalam hal nilai dan harga. Kualitas dalam hal ini mempertimbangkan pertukaran antara kinerja (atau kesesuaian) dengan harga.

Pandangan yang berbeda mengenai kualitas layanan sering menyebabkan perselisihan antara manajer dari berbagai departemen fungsional. Sifat dari layanan juga memerlukan pendekatan yang berbeda dalam mendefinisikan dan mengukur kualitas layanan. Sifat yang tidak berwujud dari layanan lebih menyulitkan proses evaluasi kualitas layanan dibandingkan dengan kualitas barang fisik.

\section{Dimensi-dimensi Kualitas}

\section{Layanan}

Zeithaml et. al. (dalam, Lovelock, et. al, 2011) telah melakukan penelitian intensif terhadap kualitas layanan dan mengidentifikasikan 10 dimensi yang digunakan oleh konsumen dalam mengevaluasi kualitas jasa. Kesepuluh dimensi tersebut meliputi berwujud, kehandalan, daya tanggap, kredibilitas, keamanan, kompetensi, sopan-santun, akses, komunikasi, dan memahami pelanggan. Dalam penelitian berikutnya mereka menemukan tingkat korelasi yang tinggi antara beberapa variabel, dan akhirnya mengonsolidasikannya ke dalam lima dimensi yang luas (Lovelock, et. al, 2011) meliputi:

1. Tangibles (bukti fisik) meliputi penampilan unsur fisik jasa;

2. Reliability (keandalan) meliputi kinerja yang dapat diandalkan dan akurat;

3. Responsiveness (responsif) meliputi kecepatan dan 
manfaat yang diberikan oleh penyedia jasa;

4. Assurance (jaminan) meliputi kredibilitas, keamanan, kompetensi, dan kesopanan dari penyedia jasa.

5. Empathy (empati) meliputi kemudahan akses, komunikasi yang baik, dan memahami pelanggan dengan baik.

\section{Model Gap (Kesenjangan) dalam} Desain dan Penyajian Pelayanan

Zeithaml et. al. (dalam Lovelock et al., 2011) mengidentifikasi enam kesenjangan potensial dalam perusahaan jasa sebagai berikut:

1. Gap 1 - The Knowledge Gap (kesenjangan pengetahuan) adalah perbedaan antara apa yang menurut manajemen senior diharapkan oleh pelanggan dengan kebutuhan aktual dan harapan konsumen.

2. Gap 2 - The Policy Gap (kesenjangan kebijakan) adalah perbedaan antara pemahaman manajemen terhadap ekspektasi pelanggan terhadap standar kualitas yang ditetapkan untuk penyajian pelayanan. Alasan untuk menetapkan standar di bawah ekspektasi pelanggan biasanya mencakup pertimbangan biaya dan kelayakan.

3. Gap 3 - The Delivery Gap (kesenjangan penyajian) adalah perbedaan antara standar pelayanan yang ditetapkan dengan pelayanan operasional di lapangan.

4. Gap 4 - The Communications Gap (kesenjangan komunikasi) adalah perbedaan antara apa yang dikomunikasikan perusahaan dengan apa yang diterima oleh pelanggannya.

5. Gap 5 - The Perceptions Gap (kesenjangan persepsi) adalah perbedaan antara apa yang disampaikan kepada pelanggan dan apa yang pelanggan persepsikan terhadap suatu layanan (terkadang pelanggan tidak dapat mengevaluasi kualitas pelayanan secara akurat).

6. Gap 6 - The Service Quality Gap (Kesenjangan Kualitas Pelayanan) adalah perbedaan antara apa yang pelanggan 
harapkan untuk mereka terima dengan persepsi mereka terhadap pelayanan yang disampaikan.

\section{METODE PENELITIAN}

\section{Rancangan Penelitian}

Penelitian dilakukan dengan metode kuantitatif yang menekankan analisisnya pada data numerik yang diolah dengan metode statistika deskriptif. Statistika deskriptif merupakan metode statistik yang digunakan untuk mengumpulkan, meringkas, menyajikan dan mendeskripsikan data sehingga dapat memberikan informasi yang berguna. Data yang disajikan dalam statistika deskriptif biasanya disajikan dalam bentuk ukuran pemusatan data (mean, median, modus), ukuran penyebaran data (standar deviasi, varians), tabel, grafik (histograms, pie, bar) (Nisfiannoor, 2013).

\section{Populasi dan Sampel}

Populasi dalam penelitian ini adalah seluruh investor di Galeri Investasi UBM yang berstatus sebagai mahasiswa aktif UBM, dengan kriteria pernah mengunjungi Galeri Investasi UBM di lantai 2. Kriteria ini ditentukan berdasarkan pertimbangan bahwa mahasiswa tersebut memiliki kemampuan untuk mengisi kuisioner tentang kualitas pelayanan di Galeri Investasi UBM. Populasi dalam penelitian ini tidak dapat diketahui secara pasti karena nama investor yang tercatat di Galeri Investasi tidak selalu berupa investor perorangan, tetapi dapat berupa kelompok investor dengan jumlah yang beragam. Jumlah responden ditentukan berdasarkan pendapat Hair et al. (2010) yang menyatakan bahwa besar sampel minimum adalah lima kali jumlah indikator penelitian, dan lebih disukai apabila besar sampelnya adalah sepuluh kali dari jumlah indikator. Pada penelitian ini peneliti menyebarkan 200 kuisioner, tetapi yang dinyatakan lengkap dan layak dijadikan data penelitian sebanyak 177 responden.

\section{Metode Pengumpulan Data}

Metode pengumpulan data dalam penelitian ini adalah wawancara, observasi dan kuisioner. Wawancara merupakan proses memperoleh data untuk tujuan penelitian dengan cara tanya jawab, sambil bertatap muka antara pewawancara dengan responden. Observasi atau pengamatan langsung 
adalah kegiatan pengumpulan data dengan melakukan penelitian langsung terhadap kondisi lingkungan obyek penelitian yang mendukung kegiatan penelitian, sehingga diperoleh gambaran secara jelas tentang kondisi obyek penelitian tersebut. Kuisioner adalah suatu teknik pengumpulan informasi yang memungkinkan peneliti mempelajari sikap-sikap, keyakinan, perilaku dan karakteristik responden (Siregar, 2013).

\section{Analisis Data}

Untuk menganalisa kualitas pelayanan, terdapat berbagai metode yang dapat digunakan antara lain metode KANO, metode AHP (Analytical Hierarchy Process), dan metode SERVQUAL (Service Quality). Metode KANO memiliki kelemahan yaitu hanya menjelaskan tentang seberapa baik keadaan layanan yang menggunakan atribut yang diterapkan padahal pada penelitian yang dibutuhkan harus cara peningkatan layanan. Pada metode AHP memiliki kelemahan yaitu ketergantungan model ini berupa persepsi seorang ahli, hal ini beresiko membuat hasil akhir dari model menjadi tidak ada artinya apabila seorang ahli tersebut memberikan penilaian yang keliru (Hidayat, 2007).

Teknik analisis data dalam penelitian ini menggunakan metode SERVQUAL. Kelebihan dari penggunaan metode ini terletak pada kemampuannya untuk menangkap subyektifitas yang terjadi pada pengumpulan data yang diambil melalui kuisioner (Santos et al., 2014). Metode ini juga dapat mengetahui variabel-variabel yang harus diperhatikan untuk selalu ditingkatkan berdasarkan nilai potensial kepuasan investor sehingga perusahaan dapat mengetahui fasilitas-fasilitas apa saja yang dianggap penting dan berpengaruh terhadap kepuasan investor terhadap Galeri Investasi Universitas Bunda Mulia (Kumar et al., 2010). 
HASIL DAN PEMBAHASAN

\section{Deskripsi Responden}

Berdasarkan hasil pengumpulan data

kuisioner, maka deskripsi responden

Gambar .1

Karakteristik Responden Berdasarkan Jenis Kelamin

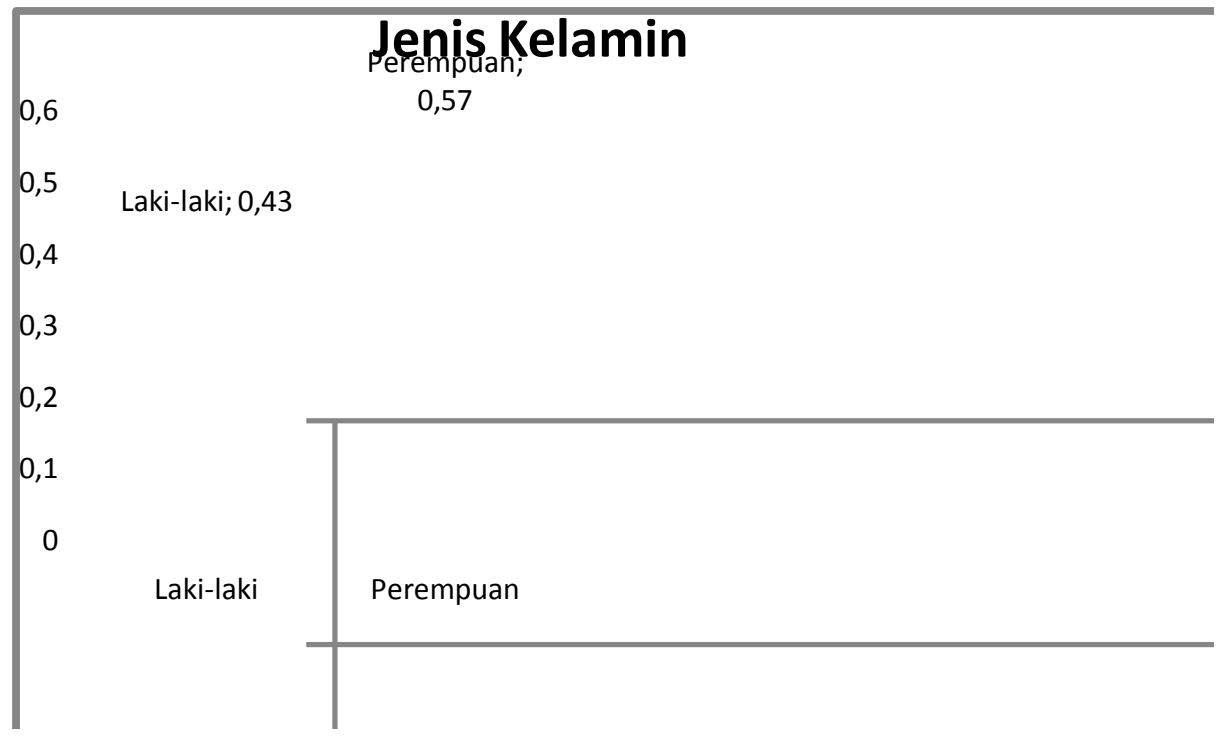

Hasil kuisioner menunjukkan bahwa dari 177 data responden yang diolah, diperoleh besarnya karakteristik responden laki-laki sebesar 76 responden (43\%) dan responden perempuan sebesar 101 responden $(57 \%)$.

Untuk karakteristik responden yang diperoleh berdasarkan tingkatan semester yang sedang dijalani, dari 177 data responden, diperoleh dalam penelitian ini ditunjukkan dalam gambar 1 sebagai berikut: 
Gambar 2

Karakteristik Responden Berdasarkan Tingkatan Semester

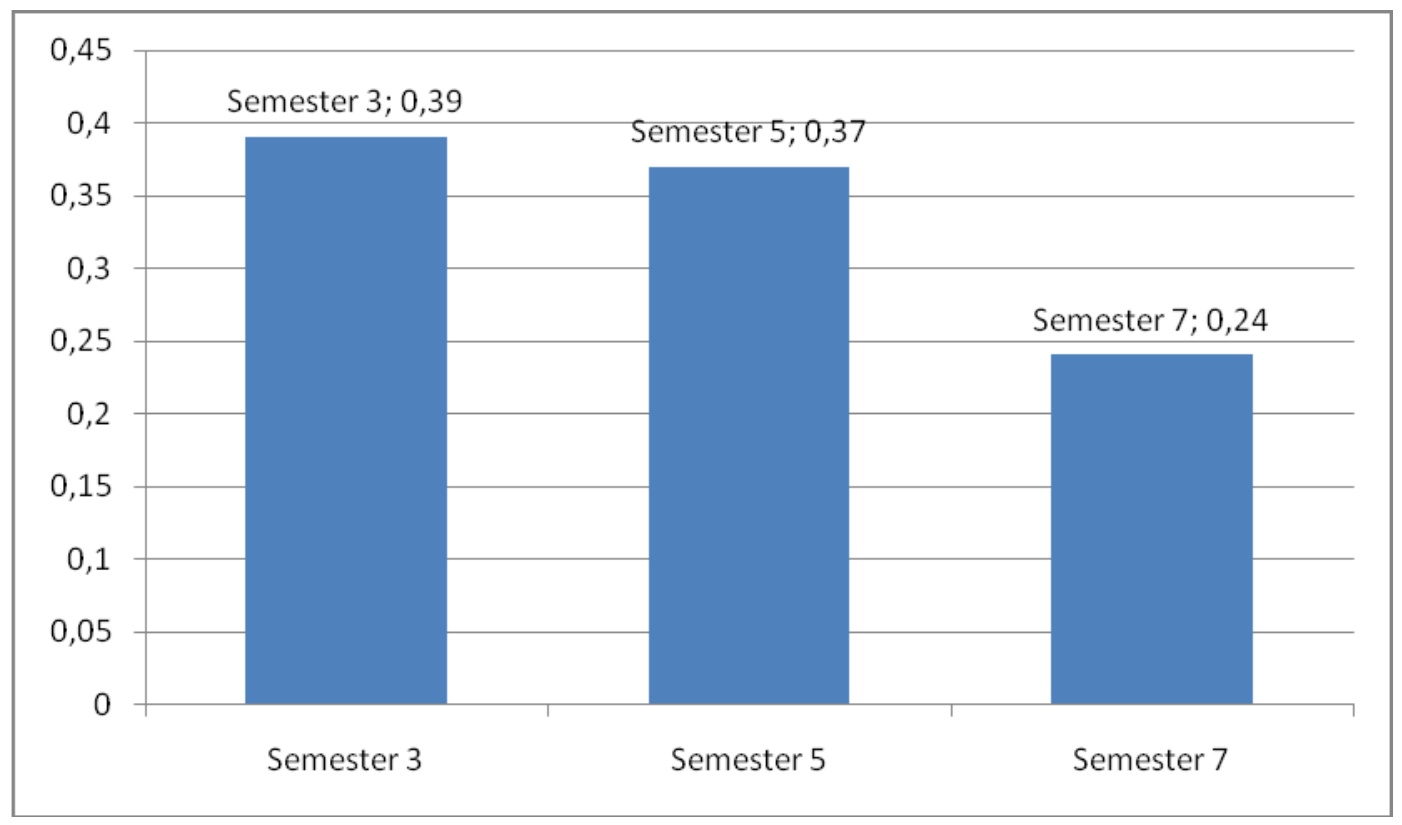

Hasil dan Pembahasan

Kualitas Layanan Galeri Investasi

UBM (per indikator)

Berdasarkan pengumpulan data

kuisioner, maka hasil perhitungan nilai rata-rata indikator harapan responden ditunjukkan dalam tabel 1 sebagai berikut 
Tabel 1

Nilai Rata-rata Harapan Responden

\begin{tabular}{|c|c|c|}
\hline No. & Indikator & Rata-rata \\
\hline 1 & Lokasi strategis & 4,33 \\
\hline 2 & Fasilitas komputer memadai & 4,35 \\
\hline 3 & Akses internet/wifi cepat & 4,31 \\
\hline 4 & Penampilan para staf yang rapi & 4,28 \\
\hline 5 & Ruangan tunggu yang bersih & 4,38 \\
\hline 6 & $\begin{array}{l}\text { Prosedur pendaftaran yang sederhana } \\
\text { (tidak berbelit-belit) }\end{array}$ & 4,39 \\
\hline 7 & Layanan tepat waktu & 4,38 \\
\hline 8 & Kesesuaian layanan seperti yang dijanjikan & 4,37 \\
\hline 9 & $\begin{array}{l}\text { Kemampuan menangani permintaan investor } \\
\text { (misalnya permintaan data keuangan) }\end{array}$ & 4,40 \\
\hline 10 & Staf memiliki pengetahuan yang cukup & 4,40 \\
\hline 11 & Kecepatan dalam menangani keluhan & 4,38 \\
\hline 12 & Memenuhi permintaan khusus konsumen & 4,33 \\
\hline 13 & Kejelasan informasi yang diberikan & 4,43 \\
\hline 14 & Kemudahan dalam memperoleh informasi & 4,44 \\
\hline 15 & Keamanan dalam bertransaksi & 4,42 \\
\hline 16 & Layanan dilakukan sesuai dengan prosedur & 4,45 \\
\hline 17 & Biaya investasi awal yang terjangkau & 4,47 \\
\hline 18 & Keadilan dalam memberikan layanan & 4,42 \\
\hline 19 & Keramah-tamahan dari para staf & 4,46 \\
\hline 20 & $\begin{array}{l}\text { Layanan khusus mengenai informasi terbaru } \\
\text { tentang trading }\end{array}$ & 4,40 \\
\hline
\end{tabular}

Berdasarkan data diatas, skor ratarata penilaian harapan responden terhadap tiap indikator kualitas pelayanan Galeri Investasi

Universitas Bunda Mulia termasuk tinggi yaitu di atas poin 4. Hal ini 
terlihat bahwa semakin besar nilai rata-rata harapan responden berarti semakin besar pula harapan responden terhadap kualitas layanan Galeri Investasi. Berdasarkan hasil penelitian ditentukan bahwa indikator harapan responden yang memiliki skor rata-rata terbesar adalah biaya investasi awal yang terjangkau. Hal tersebut menunjukkan bahwa investor Galeri Investasi Universitas Bunda Mulia sangat menginginkan adanya biaya investasi awal yang lebih terjangkau.

Berdasarkan pengumpulan data kuisioner, maka hasil perhitungan nilai rata-rata persepsi responden ditunjukkan dalam tabel 2 sebagai berikut :

Tabel 2

Nilai Rata-rata Persepsi Responden (per indikator)

\begin{tabular}{|c|l|c|}
\hline No. & \multicolumn{1}{|c|}{ Indikator } & Rata-rata \\
\hline 1 & Lokasi strategis & 4,39 \\
\hline 2 & Fasilitas komputer memadai & 3,38 \\
\hline 3 & Akses internet/wifi cepat & 2,86 \\
\hline 4 & Penampilan para staf yang rapi & 3,88 \\
\hline 5 & Ruangan tunggu yang bersih & 3,99 \\
\hline 6 & Prosedur pendaftaran yang sederhana & 3,71 \\
\hline 7 & (tidak berbelit-belit) & 3,72 \\
\hline 8 & Kesesuaian layanan seperti yang dijanjikan & 3,85 \\
\hline 9 & Kemampuan menangani permintaan investor & 3,91 \\
\hline 10 & (misalnya permintaan data keuangan) & 3,85 \\
\hline 11 & Kecepatan dalam menangani keluhan & 3,76 \\
\hline
\end{tabular}




\begin{tabular}{|c|l|c|}
\hline 12 & Memenuhi permintaan khusus konsumen & 3,73 \\
\hline 13 & Kejelasan informasi yang diberikan & 3,93 \\
\hline 14 & Kemudahan dalam memperoleh informasi & 3,93 \\
\hline 15 & Keamanan dalam bertransaksi & 4,10 \\
\hline 16 & Layanan dilakukan sesuai dengan prosedur & 4,03 \\
\hline 17 & Biaya investasi awal yang terjangkau & 3,40 \\
\hline 18 & Keadilan dalam memberikan layanan & 3,93 \\
\hline 19 & Keramah-tamahan dari para staf & 3,99 \\
\hline 20 & $\begin{array}{l}\text { Layanan khusus mengenai informasi terbaru } \\
\text { tentang trading }\end{array}$ & 3,86 \\
\hline
\end{tabular}

Berdasarkan tabel 5.2 diatas, dapat diperoleh suatu urutan nilai rata-rata persepsi dari setiap indikator mulai dari yang terkecil yaitu akses internet/wifi yang cepat sebesar 2,86 sampai dengan nilai yang terbesar yaitu lokasi yang strategis yang bernilai rata-rata 4,10 . Tetapi nilai persepsi responden yang terbesar terhadap suatu indikator belum tentu menjamin kepuasan responden pada kriteria tersebut. Kepuasan responden tidak hanya diukur berdasarkan nilai rata-rata persepsinya saja, tetapi juga memperhatikan nilai harapan responden terhadap kriteria tersebut.
Analisis Berdasarkan Perhitungan Servqual

Nilai gap dapat diartikan sebagai nilai selisih antara nilai persepsi responden dengan nilai harapan responden, atau dengan kata lain selisih antara nilai yang dipersepsikan oleh responden dengan nilai yang diharapkan oleh responden. Nilai yang positif menunjukkan bahwa pengurus Galeri Investasi UBM tidak perlu meningkatkan kriteria kualitas layanannya cukup dipertahankan saja karena dinilai sudah mampu memberikan layanan sesuai yang diharapkan oleh investor. Jika 
selisihnya bernilai negatif maka pengurus Galeri Investasi UBM harus meningkatkan kualitas layanannya karena dianggap belum mampu memberikan layanan yang sesuai dengan apa yang diharapkan oleh pelanggan.

\section{Tabel 3}

Nilai SERVQUAL (per indikator)

\begin{tabular}{|c|c|c|c|c|}
\hline No. & Indikator & Persepsi & Harapan & $\begin{array}{c}\text { Gap } \\
\text { (Servqual) }\end{array}$ \\
\hline 1 & Lokasi strategis & 4,39 & 4,33 & 0,06 \\
\hline 2 & $\begin{array}{ll}\text { Fasilitas } & \text { komputer } \\
\text { memadai } & \end{array}$ & 3,38 & 4,35 & $-0,97$ \\
\hline 3 & Akses internet/wifi cepat & 2,86 & 4,31 & $-1,45$ \\
\hline 4 & $\begin{array}{l}\text { Penampilan para staf } \\
\text { yang rapi }\end{array}$ & 3,88 & 4,28 & $-0,4$ \\
\hline 5 & $\begin{array}{l}\text { Ruangan tunggu yang } \\
\text { bersih }\end{array}$ & 3,99 & 4,38 & $-0,39$ \\
\hline 6 & $\begin{array}{l}\text { Prosedur pendaftaran } \\
\text { yang sederhana } \\
\text { (tidak berbelit-belit) }\end{array}$ & 3,71 & 4,39 & $-0,68$ \\
\hline 7 & Layanan tepat waktu & 3,72 & 4,38 & $-0,66$ \\
\hline 8 & $\begin{array}{l}\text { Kesesuaian layanan } \\
\text { seperti yang dijanjikan }\end{array}$ & 3,85 & 4,37 & $-0,52$ \\
\hline 9 & \begin{tabular}{lr} 
Kemampuan & menangani \\
permintaan & investor \\
(misalnya & permintaan \\
\multicolumn{2}{c}{ data keuangan) }
\end{tabular} & 3,91 & 4,40 & $-0,49$ \\
\hline 10 & $\begin{array}{l}\text { Staf memiliki } \\
\text { pengetahuan yang cukup }\end{array}$ & 3,85 & 4,40 & $-0,55$ \\
\hline 11 & $\begin{array}{l}\text { Kecepatan dalam } \\
\text { menangani keluhan }\end{array}$ & 3,76 & 4,38 & $-0,62$ \\
\hline 12 & $\begin{array}{l}\text { Memenuhi permintaan } \\
\text { khusus konsumen }\end{array}$ & 3,73 & 4,33 & $-0,6$ \\
\hline 13 & $\begin{array}{l}\text { Kejelasan informasi yang } \\
\text { diberikan }\end{array}$ & 3,93 & 4,43 & $-0,5$ \\
\hline 14 & $\begin{array}{l}\text { Kemudahan dalam } \\
\text { memperoleh informasi }\end{array}$ & 3,93 & 4,44 & $-0,51$ \\
\hline
\end{tabular}




\begin{tabular}{|c|l|c|c|c|}
\hline 15 & $\begin{array}{l}\text { Keamanan dalam } \\
\text { bertransaksi }\end{array}$ & 4,10 & 4,42 & $-0,32$ \\
\hline 16 & $\begin{array}{l}\text { Layanan dilakukan } \\
\text { sesuai dengan prosedur }\end{array}$ & 4,03 & 4,45 & $-0,42$ \\
\hline 17 & $\begin{array}{l}\text { Biaya investasi awal } \\
\text { yang terjangkau }\end{array}$ & 3,40 & 4,47 & $-1,07$ \\
\hline 18 & $\begin{array}{l}\text { Keadilan dalam } \\
\text { memberikan layanan }\end{array}$ & 3,93 & 4,42 & $-0,49$ \\
\hline 19 & $\begin{array}{l}\text { Keramah-tamahan dari } \\
\text { para staf }\end{array}$ & 3,99 & 4,46 & $-0,47$ \\
\hline 20 & $\begin{array}{l}\text { Layanan khusus } \\
\text { mengenai informasi } \\
\text { terbaru tentang trading }\end{array}$ & 3,86 & 4,40 & $-0,54$ \\
\hline
\end{tabular}

Berdasarkan tabel .3 diatas, jika nilai kualitas layanan menunjukkan hasil yang positif maka kualitas layanan dari Galeri Investasi Universitas Bunda Mulia hanya perlu dipertahankan saja. Tetapi jika nilai kualitas layanan menunjukkan nilai yang negatif, maka kualitas layanan dari Galeri Investasi perlu ditingkatkan. Berdasarkan hasil penelitian menunjukkan bahwa lokasi Galeri Investasi UBM yang strategis perlu dipertahankan, sedangkan akses internet/wifi di Galeri Investasi UBM merupakan kriteria yang paling perlu untuk diperbaiki karena memiliki nilai skor terendah. Hal ini juga didukung oleh pernyataan dari beberapa responden yang menyatakan bahwa akses internet/wifi di Galeri Investasi dianggap lambat sehingga menyulitkan investor yang ingin melakukan investasi ketika menggunakan fasilitas Galeri Investasi UBM.

\section{Kualitas Layanan Galeri Investasi UBM (per dimensi)}

Berdasarkan pengumpulan data kuisioner, maka hasil perhitungan nilai rata-rata harapan responden ditunjukkan dalam tabel 4 sebagai berikut : 
Tabel 4

Nilai Rata-rata Harapan Responden

\begin{tabular}{|c|c|c|}
\hline No. & Dimensi & Rata-rata \\
\hline 1 & Berwujud (tangibles) & 4,33 \\
\hline 2 & Keandalan (reliability) & 4,40 \\
\hline 3 & Daya tanggap (responsiveness) & 4,40 \\
\hline 4 & Jaminan (assurance) & 4,42 \\
\hline 5 & Empati (empathy) & 4,40 \\
\hline
\end{tabular}

Berdasarkan data diatas, skor rata-rata penilaian harapan responden terhadap dimensi kualitas pelayanan Galeri Investasi Universitas Bunda Mulia termasuk tinggi yaitu diatas poin 4. Hal ini terlihat bahwa semakin besar nilai rata-rata harapan responden berarti semakin besar pula harapan responden terhadap kualitas layanan Galeri Investasi. Berdasarkan hasil penelitian ditentukan bahwa yang memiliki skor rata-rata terbesar adalah dimensi jaminan (assurance). Hal tersebut menunjukkan bahwa investor Galeri Investasi Universitas Bunda Mulia sangat menginginkan adanya kredibilitas, keamanan, kompetensi dan sopan-santun pada Galeri Investasi Universitas Bunda Mulia.

Berdasarkan pengumpulan data kuisioner, maka hasil perhitungan nilai rata-rata persepsi responden ditunjukkan dalam tabel 5.5 sebagai berikut : 
Tabel 5

Nilai Rata-rata Persepsi Responden

\begin{tabular}{|c|l|c|}
\hline No. & \multicolumn{1}{|c|}{ Dimensi } & Rata-rata \\
\hline 1 & Berwujud (tangibles) & 3,70 \\
\hline 2 & Keandalan (reliability) & 3,87 \\
\hline 3 & Daya tanggap (responsiveness) & 3,80 \\
\hline 4 & Jaminan (assurance) & 3,95 \\
\hline 5 & Empati (empathy) & 3,66 \\
\hline
\end{tabular}

Berdasarkan tabel 5 diatas, dapat diperoleh suatu urutan nilai rata-rata persepsi dari setiap dimensi mulai dari yang terkecil yaitu empati sebesar 2,86 sampai dengan nilai yang terbesar yaitu jaminan yang bernilai rata-rata 3,95. Tetapi nilai persepsi responden yang terbesar terhadap suatu dimensi belum tentu menjamin kepuasan responden pada kriteria tersebut. Kepuasan responden tidak hanya diukur berdasarkan nilai rata-rata persepsinya saja, tetapi juga memperhatikan nilai harapan responden terhadap dimensi tersebut.

\section{Analisis Berdasarkan Perhitungan} Servqual

Nilai gap dapat diartikan sebagai nilai selisih antara nilai persepsi responden dengan nilai harapan responden, atau dengan kata lain selisih antara nilai yang dipersepsikan oleh responden dengan nilai yang diharapkan oleh responden. Nilai yang positif menunjukkan bahwa pengurus Galeri Investasi UBM tidak perlu meningkatkan kualitas layanannya cukup dipertahankan saja karena dinilai sudah mampu memberikan pelayanan sesuai dengan yang diharapkan oleh investor. Jika selisihnya bernilai negatif maka pengurus Galeri Investasi UBM harus meningkatkan kualitas layanannya karena dianggap belum mampu memberikan layanan yang sesuai dengan apa yang diharapkan oleh pelanggan. 
Tabel 6

Nilai SERVQUAL (per dimensi)

\begin{tabular}{|c|l|c|c|c|}
\hline No. & \multicolumn{1}{|c|}{ Dimensi } & Persepsi & Harapan & $\begin{array}{c}\text { Gap } \\
\text { (Servqual) }\end{array}$ \\
\hline 1 & Berwujud (tangibles) & 3,70 & 4,33 & $-0,63$ \\
\hline 2 & Keandalan (reliability) & 3,87 & 4,40 & $-0,53$ \\
\hline 3 & $\begin{array}{l}\text { Daya tanggap } \\
\text { (responsiveness) }\end{array}$ & 3,80 & 4,40 & $-0,6$ \\
\hline 4 & Jaminan (assurance) & 3,95 & 4,42 & $-0,47$ \\
\hline 5 & Empati (empathy) & 3,66 & 4,40 & $-0,74$ \\
\hline
\end{tabular}

Berdasarkan tabel 6 diatas, jika nilai kualitas layanan menunjukkan hasil yang positif maka kualitas layanan dari Galeri Investasi Universitas Bunda Mulia hanya perlu dipertahankan saja. Tetapi jika nilai kualitas layanan menunjukkan nilai yang negatif, maka kualitas layanan dari Galeri Investasi perlu ditingkatkan. Berdasarkan hasil penelitian menunjukkan bahwa berdasarkan dimensi kualitas layanan, semua memiliki skor yang negatif, artinya kualitas layanan di Galeri Investasi berdasarkan dimensinya perlu untuk diperbaiki. Dimensi empati merupakan dimensi yang memiliki nilai celah yang negatif terbesar sebesar $-0,74$.

\section{Kualitas Layanan Galeri Investasi} UBM (secara keseluruhan)

Berdasarkan pengumpulan data kuisioner, maka hasil perhitungan nilai gap berdasarkan perhitungan servqual ditunjukkan dalam tabel 7 sebagai berikut :

Tabel 5.7

Nilai SERVQUAL (per indikator)

\begin{tabular}{|c|c|c|c|}
\hline Variabel & Persepsi & Harapan & $\begin{array}{c}\text { Gap } \\
\text { (Servqual) }\end{array}$ \\
\hline Kualitas Layanan & 3,796 & 4,39 & $-0,594$ \\
\hline
\end{tabular}

Berdasarkan tabel 7 diatas, jika layanan dari Galeri Investasi

nilai kualitas layanan menunjukkan Universitas Bunda Mulia hanya perlu hasil yang positif maka kualitas dipertahankan saja. Tetapi jika nilai 
kualitas layanan menunjukkan nilai yang negatif, maka kualitas layanan dari Galeri Investasi perlu ditingkatkan. Berdasarkan hasil penelitian menunjukkan bahwa secara keseluruhan kualitas layanan di Galeri Investasi UBM perlu diperbaiki dengan nilai gap sebesar 0,594 .

\section{PENUTUP}

Berdasarkan hasil dan pembahasan pada penelitian diatas, kesimpulan pada penelitian ini adalah sebagai berikut :

1. Berdasarkan hasil penghitungan analisis gap tiap indikator (kriteria) kualitas layanan Galeri Investasi Univesitas Bunda Mulia, menunjukkan bahwa :

- Lokasi strategis dari Galeri Investasi UBM yang mendapatkan hasil positif sebesar 0,06. Hal ini menunjukkan bahwa lokasi dari Galeri Investasi dianggap sesuai untuk kebutuhan mahasiswa yang menjadi investornya.

- Akses internet atau wifi dianggap sebagai item kualitas layanan dengan nilai terendah yang harus diperbaiki, dengan nilai skor sebesar -1,45. Sebagian besar responden menyatakan bahwa akses internet atau wifi di Galeri Investasi UBM dianggap lambat.

2. Berdasarkan hasil penghitungan gap dari setiap dimensi dari kualitas layanan di Galeri Investasi Universitas Bunda Mulia, menunjukkan bahwa dimensi empati memiliki gap negatif terbesar yaitu $-0,74$. Hal ini menunjukkan bahwa Galeri Investasi perlu melakukan perbaikan dalam hal kemudahan akses, menciptakan komunikasi yang baik, dan lebih memahami investornya.

3. Berdasarkan hasil penghitungan gap dari persepsi dan harapan investor terhadap kualitas layanan Galeri Investasi Universitas Bunda Mulia secara keseluruhan, diperoleh data bahwa kualitas layanan di Galeri Investasi dianggap tidak memuaskan dengan nilai skor sebesar -0,594. Hal ini didukung oleh keterangan yang diperoleh 
dari para responden yang menyatakan bahwa akses internetnya lambat sehingga menyulitkan mereka ketika ingin menggunakan fasilitas dari Galeri Investasi. Karyawan Galeri Investasi juga tidak menggunakan seragam sehingga menyulitkan investor untuk mengenali antara karyawan Galeri atau investor Galeri ketika ingin bertanya atau membutuhkan bantuan. Responden juga menganggap bahwa informasi yang diberikan oleh pihak Galeri dianggap kurang sehingga menyulitkan bagi investor yang baru pertama kali mengenal pasar modal. Biaya investasi awal juga diharapkan lebih diturunkan lagi karena dengan investasi awal sebesar Rp. 1.000.000,- membuat investor yang berstatus sebagai mahasiswa harus melakukan investasi secara bersama-sama dengan beberapa teman lainnya untuk mengurangi biaya. Tetapi hal ini membuat kewenangan mereka untuk berinvestasi menjadi terbatas sehingga motivasi mereka untuk lebih mengenal pasar modal menjadi lebih terbatas.

Berdasarkan kesimpulan diatas, dapat ditentukan saran-saran sebagai berikut :

1. Galeri Investasi UBM perlu mempertahankan lokasinya karena investor menganggap lokasi dari Galeri Investasi sudah strategis untuk keperluan mahasiswa yang menjadi investornya.

2. Akses internet/wifi harus ditingkatkan dengan cara meningkatkan kapasitasnya atau menambah saluran pemancar wifi lebih dekat dengan lokasi Galeri Investasi.

3. Fasilitas komputer dianggap belum memadai, disarankan jumlahnya ditambah karena terdapat beberapa keluhan tentang jumlah komputer dan kualitas komputernya diperbaiki karena dianggap sangat lag.

4. Penampilan para staf dianggap belum cukup rapi, disarankan menggunakan seragam agar mudah dikenali oleh investor. 
Khusus untuk petugas dari MNC

Securities diharapkan

menggunakan seragam dari MNC

untuk menambah citra kualitas

layanan Galeri Investasi, karena

citra dari MNC Securities secara

tidak langsung akan menambah

kepercayaan investor.

5. Informasi yang diberikan juga diperjelas agar memudahkan investor dalam melakukan transaksi.
6. Galeri Investasi UBM perlu melakukan penelitian tentang kepuasan pelanggan secara berkala dan terus menerus sehingga dapat diketahui kriteria kualitas pelayanan apa yang dipentingkan oleh investor, karena harapan dan persepsi dari investor semakin berkembang seiring dengan perkembangan waktu.

\section{DAFTAR PUSTAKA}

Awan, M. U. and Mahmood K. (2010), Development of service quality model for academic library, Qual Quant, Vol. 47, pp. 1093-1103.

Ganguli, S. and Roy, S. K. (2010), Generic technology-based service quality dimensions in banking, International Journal of Bank Marketing, Vol. 29 No.2, pp. 168-189.

Hair, J. F., Black, W. C., Babin, B. J., and Anderson, R, E. (2010), Multivariate Data Analysis, Seventh Edition, New Jersey : Pearson Education, Inc.

Hidayar, A. A. (2007), Metode Penelitian Keperawatan dan Teknik Analisa Data, Jakarta : Salemba Medika.

Lovelock, C., Wirtz, J., and Mussry, J. (2011), Pemasaran Jasa : Manusia, Teknologi, Strategi - Perspektif Indonesia, Edisi Ketujuh, Jilid 2, Jakarta : Penerbit Erlangga. 
Nisfiannoor, M. (2013), Pendekatan Statistika Modern : Aplikasi dengan Software SPSS dan E-Views, Jakarta : Penerbit Universitas Trisakti.

Radder, L. and Han, X. (2009), Service quality of on-campus student housing : a south African Experiences, International Business \& Economic Research Journal, Vol. 8 No.11, pp. 107-118.

Rochaety, E., Tresnati, R., dan Latief, A.M. (2009), Metodologi Penelitian Bisnis, Edisi Revisi, Jakarta : Penerbit Mitra Wacana Media.

Seth, N. and Deshmukh S. G. (2005), Service quality models : a review, International Journal of Quality and Reliability Management, Vol. 22 No.9, pp. 913-943. 